\title{
Breaking out - Barriers against Effort, Biographical Work against Opportunity Structures
}

\author{
Zoran Slavnic \\ REMESO \\ Linkoping University, SE 60174 Norrkoping, Sweden \\ Tel: 46-11-363-211Ｅ-mail: zoran.slavnic@liu.se
}

Received: July 3, 2012

Accepted: July 16, 2012

Online Published: August 5, 2012

doi:10.5430/jbar.v1n2p1

URL: http://dx.doi.org/10.5430/jbar.v1n2p1

The research is financed by Swedish Council for Working Life and Social Research and Social Research and Swedish Agency for Economic and Regional Growth - Tillväxtverket

\begin{abstract}
This paper presents the life story of a single small-business owner of immigrant background who wants his company to grow. His business strategies are analysed both as a part of his own biographical work, and as they were influenced and framed by broader political, economic and social processes. It is shown how his own personal qualities in combination with opportunity structures in the local market provided favourable conditions for his break-in. Breaking out, however, seems to be presented with different types of barriers, such as lack of access to capital, discrimination, and the fact that new markets may consist of different sorts of network that are in its turn more difficult for new actors to enter. But even if newcomers often find these barriers difficult for to overcome, individuals are not just passive objects but also have the opportunity to realize their lives according to their own life plans.
\end{abstract}

Keywords: Ethnic business, Biographical method, Mixed embeddedness, Trust, Work ethic, Break-in, Break-out, Integration, Opportunity structure

\section{Introduction}

Research on small businesses owned by immigrants has been conducted for almost 40 years. For a long time it was dominated by American research traditions, based primarily on cultural explanations. These explanations maintained that ethnic resources, such as cultural tradition, trust and loyalty relationships based on ethnic solidarity, were crucial for immigrants' social and economic integration into mainstream society.

This approach, which was both theoretically and methodologically rather one-sided, came to be increasingly questioned during the 1980s. An increasing number of researchers, primarily in Britain (Note 1), moved the focus from cultural explanations to structural explanations. They began to study how the capitalist market, along with state regulation, affected immigrant entrepreneurs' activity.

However, the concept that has become most popular in recent years is that of mixed embeddedness (Note 2). This concept does not exclude the relevance of social and cultural networks for social and economic integration, but these networks are affected by society's broader economic, political and social processes. In other words, it is clear that immigrant entrepreneurs' economic success to a certain extent depends on their ability to mobilize their networks, but it is equally clear that their activities depend even more on the situation and internal dynamics both of the specific markets in which they operate and of governmental regulation of these markets.

Immigrant entrepreneurs' business strategies are therefore - apart from factors such as individual qualities and ethnic networks - embedded both in the markets in which they operate and in the actual regulatory frameworks that together, and in various ways, affect their economic activities. Both markets and regulations have, in turn, their own dynamics, which vary locally, regionally and nationally. Kloosterman and Rath (2001) suggest therefore that the interaction between ethnic strategies and opportunity structures (markets and regulation) should be analyzed 
comparatively at three levels - national, regional and local (or neighbourhood). This methodological approach is, in my view, suitable for the analysis of the empirical material on which this paper is based.

This is not all, however. An important methodological point must be made in this context. This paper is about the life story of a single entrepreneur. His name is Orhan, and his individual perception of reality, his strategies for finding his own way through this reality - in a word, his biography - are the starting point for my analysis of the social processes at all those aforementioned levels. So I adopt a biographical perspective in my analysis.

Applying the biographical method in social science involves trying to understand how individual biographies design current social processes on the one hand, and how social processes create individual biographies on the other (Rosenthal, 1993; Alheit, 1994; Apitzsch and Siouti, 2007). Individuals create their biographies by constantly reinterpreting their lives in response to current social processes and social structures. This process is called 'biographical work' or 'biographicity' (Alheit, 1994). Although during this process individuals often have to accede to the pressure of the powerful social structure, they often do not feel subordinate but rather retain a sense of autonomy and control over their own lives (Alheit, 1994). This dynamic process is actually a synthesis of social structure and individuality (Apitzsch and Siouti, 2007), and my ambition in this chapter is to try to 'capture' at least part of this complex dynamic.

Before I begin Orhan's life story, I will first present several relevant theoretical concepts, namely, concepts of work, trust, and break-in and break-out business strategies.

\subsection{Different views on work}

Work may be perceived as a way to satisfy basic needs or as an essential part of one's identity. It can also be seen as a sense of duty or as a contribution to the development of universal human nature (Wright Mills, 1951/2002). These different perceptions of the meaning of work, according to Wright Mills (1951/2002: 215), arise because work had different meanings in different historical periods. In ancient Greece physical work was carried out by slaves, because free people were not used to engaging in physical labour. In the Middle Ages work had not yet any value in itself, but served either as a punishment for sin or as a possible way to obtain the mercy of the higher powers. It was first with Martin Luther that work occupied a central place in human life: everybody who can, should work; not to work is sinful (Wright Mills, 1951/2002: 216).

Parallel to this view of the nature of work, an idea developed during the Renaissance of work as a creative activity, where people expressed their true creative nature. Pico della Mirandola launched an idea of homo faber, 'man as his own creator' (Sennett, 1998).

These two visions of work - the Lutheran view of as self-discipline, and the Renaissance view of work as self-realization - came together in the notion of the work ethic elaborated by Max Weber (Wright Mills, 1951/2002: 98). According to Weber, self-discipline must be understood as a 'discipline of time', which means that people must be prepared for the delayed gratification from the fruit of their labour. The creative aspect of the work ethic affects life in general. People should understand their own life trajectories as a totality in which they finally achieve a tangible result (Wright Mills, 1951/2002: 98).

Wright Mills and Richard Sennett agree that the work ethic as described here has lost its importance today, since '[f]or most employees, work has a generally unpleasant quality' (Wright Mills, 1951/2002: 219). According to Sennett (1998: 99), the reasons for this are to be found in the instability of social institutions. The traditional work ethic described above cannot be retained in today's circumstances, when the institutions of society are subjected to such rapid change.

It is important to mention in this context the historical work ethic of middle-class entrepreneurs - 'craftsmanship', as Wright Mills (1951/2002:220-2) called it - which in his view does not have much in common with work ethic of small business today.

According to Wright Mills (1951/2002:220-2) there are six main elements of this idealized model of the relationship to work:

1) An inner relationship exists between the craftsman and his or her work and products.

2) Although craftsmen often do not legally own the objects they produce, they own them psychologically, as visible and material results of their work.

3) Craftsmen are free to organize their work according to their own timetables.

4) Craftsmen perceive their work as a tool for developing not only their skills but also their personalities. 
5) There is no gulf between work and play, or between work and culture.

6) The craftsmen's work is equal to their life essence - 'The craftsmen's work is the mainspring of the only life he knows; he does not flee from work into a separate sphere of leisure' (1951/2002: 222).

Wright Mills of course treats this work ethic as an ideal type, something that never existed in reality but whose individual elements nevertheless are included in every craftsman's biography. The question of how Orhan's work ethic measures up to this ideal type is one of the questions that this paper tries to answer.

\subsection{Different levels of trust}

Trust is an important element in securing normality in our everyday lives, and it may be discussed at several levels.

The first level is the one that Jack Barbalet (2009) has called 'generalised social trust', which is equivalent to what Giddens (1990) describes as a positive or optimistic relationship towards other people, social institutions and the future. Without this kind of general trust that people have in society and its institutions, society would disintegrate (Simmel 1990: 178-9). The experience of this kind of general trust and a sense of ontological security are very closely related (Giddens, 1990: 92).

The second level is related to the concept of trustworthiness, which is our commitment to fulfilling the expectations of, or winning the respect of, other people (Misztal, 1996). According to Sennett (2003), it is possible to distinguish three general strategies in how people try to gain respect. The first is through self-development. Investing in one's own professional or intellectual development usually results in winning respect. The second is to ensure self-sufficiency: unlike social parasites, self-sufficient individuals deserve respect. The third is to give to other individuals and to society.

Finally, at the third level, according to Piotr Sztompka (1999: 71-8), there are three bases from which we can win trust in our direct interactions with other people. These are reputation, performance and appearance.

Reputation is the sum of all past performances. Trust in this sense accumulates as a kind of capital that will provide greater opportunities for future action, but also obliges individuals to continue to meet other people's expectations. The problem with reputation is a kind of asymmetry between the accumulation of reputation and the loss of it (Sztompka, 1999: 71-8). The process of building a good reputation is often difficult and lengthy, whereas a good reputation can be lost, or transformed into disrepute, easily and quickly.

Performance is related to the actual result of action oriented towards providing the trustworthiness. As such, it is a less reliable basis for trustworthiness than reputation, because high performance in the present does not guarantee equally high and consistent performance in future (Sztompka, 1999: 71-8).

Appearance, the third basis for trustworthiness, denotes external, superficial expressions of confidence such as clothing, posture and behaviour. Despite its external and superficial character, these signs can often be crucial to establishing trustworthiness, because they can cause spontaneous and strong feelings of trust and distrust (Sztompka, 1999: 71-8).

\subsection{The concepts of break-in and break-out}

The concepts of break-in and break-out have been established in the research field of immigrant small businesses with the aim of explaining the strategies used by small entrepreneurs with immigrant backgrounds when they want to get rid of the 'immigrant' stamp on their businesses and to integrate in so-called mainstream markets which have no local or ethnic character (see Ram and Hillin, 1994; Engelen, 2001; Ram et al., 2003; Levent et al, 2006). According to this account, most small businesses owned by immigrants enter the market ('break in') by focusing on ethnic networks and on traditional products and services that are sold mostly to customers within their own ethnic groups (Levant et al., 2006: 143). 'Break-out' strategies can be defined as strategies that enable these small businesses to break away from the local or ethnic markets where they first established themselves, and to become part of the mainstream economy (Levant et al., 2006: 144).

In this paper, I use the concepts of break-in and break-out in a slightly more neutral way, by removing their excessive emphasis on ethnicity. Here the concept of break-in refers to a situation where a new operator enters the market, for example when a small business establishes itself within a specific geographical area or market segment. After a while, those small businesses that have the ambition to grow must either win a larger share of existing markets or win new, more profitable markets. Such new markets may be in new geographical areas or in new sectors. This process of winning new markets is here called break-out. 


\section{A difficult but a successful start}

When I first met Orhan in 2004, he owned a small metal company in the Malmö harbour area with about five employees. When we met again five years later, he had gone through a 'recovery period' following the severe worldwide economic crisis of autumn 2008. Orhan had had on his books at most around a hundred employees, a number that later was significantly reduced due to the crisis. When we met in September 2009 he had about 30 employees left.

Orhan came to Sweden in the early 1990s as a war refugee from Bosnia-Herzegovina. In his homeland he had, at the beginning of his working life, spent 15 years as a metalworker in a major construction company. During the 1980s the economic crisis in former Yugoslavia deepened. Unemployment was high, and the economic situation was not much better for those who still had their jobs. In the mid-1980s Orhan decided to start his own business. He described the first two or three years as a truly difficult establishment period. Eventually the business prospered and the last two years before the war started, as Orhan put it, were really good. After about five years in business, he was forced to leave his homeland and flee to Sweden.

War, persecution and exile meant a radical change in Orhan's everyday life, in which he had hitherto felt secure. This kind of security is what Anthony Giddens $(1984 ; 1990)$ calls 'ontological security'. The term stands for a kind of internal security, a sense of continuity and order of things, and events that the modern person's daily life is based on. The feeling of such security can be achieved only if daily life is organized around predictable 'routines'. The routines in themselves create the structure, a tone of normal everyday life, but are nevertheless, however necessary, not sufficient to guarantee normal everyday life.

The modern person cannot create a normal everyday life without feeling confident in other people (to find support in their reliability, honesty or love), without trust in 'abstract systems' (supported by expert knowledge and technology) and, not least, with an orientation towards the future (organized and controlled) as a means of connecting the past with the present. For the whole to function, according to Giddens (1984) people develop a whole range of skills in communicating with other people, such as tact, as well as respect for the needs of the people they communicate with.

In certain life situations, however, which Giddens (1984) calls 'critical situations', radical disruptions occur in the normal everyday lives people are used to and feel comfortable with. Such a critical situation was caused in Orhan's life by, as mentioned, war, persecution and exile.

\subsection{The quest to reconstruct normality}

Orhan's first and instinctive step in attempting to re-establish a normal life in Sweden as soon as possible was to reintroduce one of the most important routines of his life, namely, work.

Can you imagine that I started working after only my third day in Sweden. Once in the refugee camp, I awoke the first morning and wondered what I was going to do. I was so used to working every day, good Lord, what should I do now. I asked my son, who could speak English, to speak to our administrators to see if there was something to work with there. When he returned, he told me that if I wanted to I could paint the chairs and tables around the camp. I accepted the task without thinking twice. So next day I started painting, while other refugees looked at me and sarcastically asked why I was working without being obliged to do so.

The relationship to work is never just a question of whether to work or not to work. For Orhan it was lot more than just 'to work', it was part of his identity. To become dirty during work or to put his back into the work, for example, was not a problem for him but a habit.

For me it's no problem to get a little dirty in my work, if work is of such a nature. Had this not suited me, I could simply have chosen another profession. There are people who are afraid to engage in such work, when needed. In the company where I worked at home, I was responsible for technical maintenance. Sometimes the cable on a construction crane would come off. Changing it was a very dirty job because of all the machine grease. It used to be so dirty so that it could take several days to remove all dirt. But the job would still be done. I learned this attitude there and I have carried it with me ever since.

A few months later his family moved to another refugee camp, where he was able to start studying Swedish. It meant a further step forward in his efforts to reconstruct normality in his everyday life. The ability to communicate is a prerequisite for restoring trust relationships with other people. At the same time he got a job. He told the people at 
the local social services office that he would like to work. They helped him find an internship on a farm not far from where he lived.

\begin{abstract}
You know, in Sweden it is common with farms near large cities, which serve as some kind of campus for schoolchildren to get acquainted with different types of animals. The man who owned that place could provide accommodation for an entire school class; he also had some cows, sheep, goats, ducks, chickens, pigs and so on. My job was to help him to run this his farm. Among other things we use to chop wood together ... I could not say a word in Swedish, but we worked together and somehow we understood each other... So, I worked four hours each day and then would rush home and change and go to school. This was not easy, but it was my choice, because I did not want to sit at home idle.
\end{abstract}

This quoted passage makes it possible to reconstruct Orhan's strategy for re-normalizing his life. The focus is on work and trust. Trust, as we shall see in Orhan's case, manifests itself as a generally positive relationship towards other people, social institutions and the future. Orhan also tries to win trustworthiness and respect by fulfilling the positive expectations of others.

Work and the work ethic are the main means he uses. It should be noted here, and it will be confirmed later in this paper, that his work ethic may be described as somewhat old-fashioned and rather rare in our time. For most employees work is generally, as mentioned, an unpleasant experience (Wright Mills, 1951/2002; Sennett, 1998). In Orhan's case, there is instead some kind of internal relationship between him and his work. He experiences work both as a mean for developing his craft skills and as a mean for his own personal development. In this respect his work ethic roughly corresponds to the traditional craftsman's work ethic as described by Wright Mills (1951/2002: 220). I shall return to this point later.

\title{
2.2 Starting up
}

In 1994, after being granted the right to permanent residence, Orhan's family moved to a small community outside Malmö. In those days it was difficult to get a job at all, especially for newly arrived immigrants. For Orhan was the only realistic solution was to start studying at AMU (Note 3), where he spent one year combining language study and training. In his view this period was not a waste of time, since he learned the Swedish language and another one profession. He had previously worked as a locksmith and welder; now he learned to operate lathes, which greatly helped him later when he established his own firm.

After he completed his education, he obtained an internship for six months in a small company. The plan was to obtain permanent employment there, but over time he realized that the chances for this were small. The employer gave him unclear signals all the time. Orhan had a kind of feeling that the boss just wanted to use him as a black employee. Finally he tired of the uncertainty and took the decision to start his own business. He reasoned in this way:

Firstly, I had previous experience as self-employed, second, I had nothing to lose, the worst that could happen was that I could live on welfare, which I already did. So this was my way of reasoning...

In those days it was not difficult to find vacant workshops in Malmö. Orhan simply took a turn by car around the industrial area at the port and saw a notice 'workshops to let'. In this industrial area all the workshops were empty. The owner of this particular one had run a business with 80-90 employees, but had moved it to another place in southern Sweden.

Let me here make a brief digression on what kind of role local conditions played for Orhan. The first 'push' factor was, of course, lack of any opportunity to obtain a regular job. This factor tends generally to be one of the important reasons why immigrants start their own business in Sweden (Mason and Ålund, 2001; Andersson and Wadensjö, 2004b;).

The second important factor had more to do with the local market in Malmö. That local market was in a state of turbulence during the 1980s and 1990s. The traditionally industrial city suddenly began losing its industrial base. In 1987, after many years of weakening and decline, one of the local symbols of the old industrial era, Kockums workshop, was closed down. The major part of the civilian ship production industry, which used to employ around 3,000 staff, disappeared (Lundin, 2007). As Kockums vanished so did jobs - on some estimates 6,000-10,000 (Lundin, 2007: 30) - and also demand for the products of a large number of small businesses in the region which previously had been subcontractors to Kockums. Many businesses were closed while some moved their operations to other parts of the region. The large number of empty workshops in the port's industrial zone was a visible sign of the depth and extent of these changes. 
The rapid dismantling of the metal industry in Malmö probably resulted in a kind of vacuum - the market that had been vacated by Kockums as it shut down was inadequate to sustain the small businesses that previously were Kockum's subcontractors. As result, many subcontractors were also forced to shut down or to move somewhere else. In turn, long into the 1990s the demand for metal products and services in Malmö could not be satisfied by the existing supply.

At that very moment Orhan arrived with his company, which was ready to offer the kind of products and services demanded on the market. At the same time the owners of the empty workshops in the area were happy to be able to let them.

Orhan decided to try to rent one of the empty industrial workshops in the industrial area in Malmö.

... and so I contacted him [the workshop owner]. I perceived him as a serious, middle aged, Swedish businessman. He, however, was initially suspicious of me, which is normal given that it was the first time he saw me. He told me that there would be no problem with the lease but that I would have to have a credit guarantee from the bank. The bank, however, rejected me without further ado ... at that time I did not have my own capital ... without your own money, you get no credit guarantee from the bank...

The banks' attitude towards small entrepreneurs in Sweden is generally such that it often restrains the development of small businesses (Slavnic, 2007; Rath and Swagerman, 2011), a topic we return to below.

However, Orhan's strategy of gaining people's trust through work and personal loyalty proved to be an effective way for him to acquire social capital. In this particular case, it helped him to solve his business problem. As a refugee in Småland he had already met a Swedish man whom he later befriended and who turned out to occupy an important position on one of the big bank's boards. He helped Orhan to obtain bank guaranties and to rent his first workshop. The workshop that Orhan moved into in 1998 had not been used for several years and was in a very poor condition. It has suffered several burglaries, and most of the doors were broken and could not be closed. The fence was broken in several places.

Nothing worked as it was in the workshops. My landlord asked me if I could repair the doors of the other industrial buildings in the area ... which I eventually fixed. He obviously noticed that I was handy, and since then it was always me that he hired if he needed to get things done.

As a number of machines had been left in the workshops, Orhan agreed with the owner to take them as payment for work he did for him. In this way, he could gradually build up his own machinery.

\subsection{Production vs. hiring of manpower}

This was the way Oran established his business. Right from the start, however, his business stood on two pillars. One was Orhan's own business and his network of customers. The other was the selling his manpower to other companies that needed workers. He started this part of his business by contracting his own work. Orhan went to the junkyard and worked as long as there were jobs, sometimes for a month, sometimes longer. The rest of his time he spent in his workshop with the ambition of developing the business while there.

What did he think himself about doing temporary work for larger companies?

This is how the current system works. Many larger companies have earned big money in that way. They receive assignments and know they are going to need manpower only a few months ahead and so it is best not to employ people in that period but to hire workers instead ... in this system they know that if the worker who is hired becomes ill, for example, he is going to be replaced by a second, third, and so on. I'm not the only one who works in this way, but many more companies are doing just the same way...

The quotation above illustrates an important trend in Western economies that is global in its nature. It is about outsourcing as an adjustment strategy of large companies, but also about an increasing trend of in-sourcing the workforce (Purcel and Purcel, 1998). The trend is also evident in Sweden today and shows no signs of weakening (Andersson and Wadensjö, 2004a; Olofsdotter, 2006, 2009). This not only gave Orhan his first job but also had the result that outsourcing the workforce was from the beginning a major part of his business, much larger than the sale of products or services.

The expansion of the number of manpower companies, and the renting of the workforce as an industry, however, is not without its problems. Increased flexibility for large companies is certainly an advantage from this development. Those who are critical of these trends point out the risk that employees may be exposed to increased exploitation, 
with the standard employment contract becoming an increasingly endangered species and the potential for conflict in the workplace between groups working under different types of employment contract (Olofsdotter, 2004, 2009).

Because of these problems, the role of managers in temporary employment agencies is extremely demanding and complex (Olofsdotter, 2006). Managers are expected to have good relationships with both client companies and the so-called consultants - that is, the workers who are leased to the client companies - but without the ability to influence the situation in the client company. Orhan's ability to develop and maintain relationships, characterized by trust towards and cooperation with both employees and client companies, appears to be the most effective way to engage in this activity.

Orhan himself, however, claimed that his ambitions in the long run were still attached to his own activities, to develop production and to provide the market with one or more of his own products. At the same time renting his workforce to big companies still provided too much revenue to be given less priority.

During that period Orhan won a long-term contract with the city of Malmö for the maintenance of its metal garbage containers. He was even given an inspection certificate.

This means that I am myself looking for damage. They send you containers and do not check what exactly is wrong with them. So, in fact, I can find as many fictitious defects or as much damage as I want. We do, of course, not this, because it is bad strategy ... You can cheat but it is always a short-sighted strategy, and the consequence may be that you lose the contract. You have to take care of your customer.

For Orhan this strategy of long-term cooperation, based on trust and the quality of the work - seems very important.

What was his relationship with his own employees? At the time when the issue was discussed, he had four employees, and hoped to recruit some more. The first employee was a man from Lebanon who had never done this kind of work. Orhan had given him job training and the man turned out to be very good. 'A natural intelligent guy who uses his head and who has learned quickly,' said Orhan. Furthermore, he had a Swedish man among his employees. 'He is 60 years old but it is difficult to find such a capable worker.' The other employees comprised two Bosnians, one with permanent employment and the other on six months probation. Finally, there was another young Swedish worker who was in the recruiting process.

I'm very pedantic and strive to ensure work is properly done. This is what I require from my employees, too. I have never hurried up my workers. Never. This Swede, for instance ... I told him once that he should take it easy, he did not need to rush. He told me that he was forced to speed up all the time in his last job. I said I am more interested in getting the job done properly, even if it takes longer for it always costs more if you do a bad job, and have to discard the product and make a new one.

This quote reaffirms my earlier conclusion about Orhan's old-fashioned work ethic. If you want to grow, for instance, the motto 'better slowly with good quality, than quickly with a lack of quality' seems to be rather problematic. Of course, entrepreneurs can invest in product quality as a part of their process strategy, or they can also invest in cost reductions. The emphasis on quality does not, however, mean that entrepreneurs can ignore the costs. If they want to survive in the market, they will sooner or later be forced to do something about the quality-related costs.

\subsection{Skepticism towards ethnic networks}

How then is possible to characterize the influence of the ethnic network on Orhan's way of running a business? Did he prefer Bosnians, his countrymen, in his cooperation with other small and medium-size enterprises (SMEs)? Or did ethnicity play no role in this context?

I do not know. My experience is predominantly poor. One example is a Bosnian who has started his own business and asked me to make an advertising holder for him. I did it, sent it to him... and look at his business ethics now! The due date for payment was one month, and I did not get paid from him until after six months, after I had sent a reminder ... I tell all this to you to give you examples of how it should not be done, because it is not possible to do business in this way.

In spite of his criticisms, we can see that from the outset Orhan had some Bosnian employees. He even tried to forge business relations with small businesses owned by other Bosnians. But my overall impression was that his ethnicity definitely neither motivated him to start his business nor influenced his decisions on how to run his business. He simply did not build his business strategies on his ethnic network. Some research shows that this certainly applies in the case of other Bosnian immigrants in Sweden (Povrzanovic-Frykman, 2009; Slavnic, 2007) and in other countries 
such as Canada (Bauder, 2005). According to these studies Bosnians often view the use of ethnic networks as kind of illegitimate favouritism, and that is why they prefer to try to build their future on their own professional skills and formal qualifications.

To draw more reliable conclusions, we need more scientific results. Nevertheless, Orhan's stance towards the ethnic networks constitutes in itself a major challenge to the powerful discourses that I mentioned in the introduction, in which the economic integration of immigrants is viewed as predominantly based on cultural factors.

\subsection{Breaking in}

The start-up phase of Orhan's small businesses, from the prospect of the concept of 'mixed embeddedness', could be summed up as follows.

I start with Orhan's personal qualities and the network he needed for his establishment and survival. His attitude to work - involving punctuality, reliability, quality, loyalty - had obviously given him a good reputation and helped him to keep his customers once he had acquired them. As for his ethnicity, it is apparent that he has not used primarily the ethnic network. Rather, he trusted his own professional and personal qualities, and the network he built up on business rather than ethnic grounds.

The structural context in which he started his company in turn had a number of important features. One of them was high unemployment in general and high unemployment among immigrants in particular. Consequently, many immigrants, not only at the local level, in Malmö but also nationally, were forced to start their own businesses, in a situation where they otherwise could not get a job at all. Another feature was that developments in the local market led the traditional industrial structure to dissolve. The consequences of this situation in the industrial sector where Orhan started up seem to have facilitated the establishment of his company. In addition, the global in-sourcing trend made possible the steady development of that part of his activities that consisted of supplying a temporary workforce to large companies.

Finally, public political discourse at all levels had in various ways supported the creation of small businesses in general and immigrant small businesses in particular (Slavnic, 2007).

All these aspects of interaction made it possible for Orhan's company to make its break-in, that is, to establish itself and survive in the local market.

\section{Five years later}

My next meeting with Orhan took place five years later, in autumn 2009. Much had happened since the last meeting.

Orhan had moved his business to an industrial plot of $7,000 \mathrm{~m}^{2}$, of which almost $3,000 \mathrm{~m}^{2}$ were occupied by industrial buildings. Orhan met me in his big office.

Out in the workshops he showed me his first new press brake, which had a capacity of 240 tons and managed to bend three meter-long items. He declared proudly that perhaps only two or three companies in Malmö had a press brake with the same capacity. The premises also included a new power shears, which could cut plate $16 \mathrm{~mm}$ thick and four meters long. The job had continued to evolve along two tracks: production and services on the one hand, and supplying employees to larger companies on the other hand.

This was the year after he had about 100 employees, and after the great financial crisis of 2008 he had to cut his workforce to about 30 employees.

Do you know how it happened? The crisis came like lightning from a clear sky. At that time we had our people in a large metal company. We had 13 workers and we were about to come in 'through a large door'. There were a further two companies, but since we had more skilled workers, our partner fired them and hired our workers. We offered good wages to our employees, in order to have quality and to be able to get this contract. ... So, it was a good start and we had great expectations of this project, when the crisis came.

Shortly before the crisis, when Orhan started supplying his workers to the large metal company, the company was doing a lot of work for China. It made particular mills for the stone used in road construction. The job went so well that it could produce mills without orders for them - the risk of not selling them was virtually non-existent. When the crisis came the company had a year's production of mills in stock, and production was organized in three shifts. This resulted in the dismissal of a large group of employees, as well as the termination of the contracts for temporary personnel. Orhan's contract with this company, as well as with other large companies, was also affected by the process. 


\subsection{Conflict-free notices, continued focus on staffing}

Finally, Orhan himself was forced to fire his employees.

Some workers I have left working, for example for two months, depending on how long they were employed. I just kept them for two months, the period of notice. Those who had been employed for a short time I got to keep for one month. ... Then we had to discuss this issue with the union. Our problem was how to maintain excellence while respecting the rule 'last in, first out'. They were rather tough in the beginning, but eventually we reached some sort of compromise.

When I asked about his relationships with the redundant workers during the dismissal process, he replied:

I have never been in conflict with any of my workers. A lot of people were made redundant but we have never at any point had a conflict. They understood the situation, they saw what it was about, and there was no problem. Now I have re-hired some of them. ... They were very happy when I called to them.... I always give priority to my former employees.

Labour hire was still an important part of his business. Even in the current situation, when Orhan had 'only' 30 employees, two-thirds were supplied to other companies, and only a third worked in the main activity. Orhan still claimed that his highest ambition was to have his own product and production.

In our conversation it became clear that the structure of opportunities for his business systematically paved the way for the staffing business. It was equally obvious was that his production activities, even if not perhaps directly prevented, were at least not at all stimulated by actual opportunity structures. Later in this chapter we will see that such forces continue to frame Orhan's business as a staffing one, despite his painstaking efforts to develop it in the opposite direction.

\subsection{Measures for increasing production and raising skills}

Orhan's production activities were still based on individual orders and service. During the aforementioned crisis, for instance, the contract with the municipality for the maintenance of garbage containers was a sort of surety for the rest of his business operations.

For the future, however, he planned to adopt, or had already adopted, several measures aimed at increasing his own production. Among other things, he had already prepared the necessary documents to obtain two significant international certificates: ISO 9001, which regulates quality, and ISO 14001, which regulates the environment.

There are not many companies in Sweden that have these certificates, perhaps up to 10 per cent. The advantage of the large companies ... is that they already have it but they also require it of their partners and customers. So if I managed to get it, I would have a better chance to obtain orders from the majors.

Another important element of Orhan's strategy was the recruitment and training of skilled labour. He was aware that that all companies were generally very determined to keep their most skilled workers. That is why he got involved, in collaboration with the Employment Service, in a project focused on training and selecting new workers.

We had this one idea, why not educate our own employees? In this way, we know what we get. So we signed a contract with the City of Malmö, we went to a school and chose the people ourselves. We selected candidates with regard to their interests and knowledge. And then they first spent several months in school, where they read a little maths. Then they came to us and were under six months of practical training. It was a good program to make perfect professional workers...

In addition to cooperating with the Employment Service, Orhan tried to advertise, and then to select people based on those who responded to the adverts. These two methods, according to Orhan, were the only way to get talented and skilled workers: either through a careful selection process or through in-house training. To recruit workers directly from the Employment Service was not viable because then you have both to pay them and to train them, and nobody want to do it nowadays, as he put it.

Again I asked about the ethnic structure of the staff.

I have all the time had people from all continents. I have obviously had Bosnians, but I have also had Chileans, Indians, one from Sumatra. I have of course Swedes, they are either a majority or a minority. I like to joke and say 50:50, we employ even the Swedes. But you know, we are predominantly immigrant businesses. Our names may ensure that those more qualified Swedes do not dare come to us. Yet, in that training project which I talked about earlier, it was mostly Swedes. 
As for the rest, Orhan's ambition was to have this type of worker come to work in the morning, get a drawing in hand, get information about the time frames, and then work.

To achieve this, an important condition is to have a good management, he said. He tried to find someone to replace him, because he needed to concentrate on developing the company. He was simply no longer able to work both in production and in the office. But it was not easy to find such a person.

\section{.. I first hired a man, I had advertised in the newspaper Sydsvenskan. I even hired a consultant to help me with the selection. And we found a man but the problem was that the man had no experience in the job as supervisor. He was a skilled worker, but he had no good way to deal with people. He had no tact. And what has been the use of such a man? After the probation period of three months, I could only thank him for the work he'd done and that was all.}

Later, Orhan promoted after all one of his older and more experienced workers to the position of supervisor. The man had already become accustomed to his new job, but was still making a lot of errors. The transition period is not over yet, Orhan said.
Maybe I expect too much from him, but you cannot get everything that I expect at the same time. I'm trying to drop everything for him ... I'd rather not get involved, but I must. ... Almost every morning, even today, I used to change into work clothes and go to the workshop. My purpose is of course not to work in production, but to improve the atmosphere there.

\subsection{The crisis: total control, and job satisfaction?}

Orhan was confronted at this time with problems faced by all small business owners whose businesses start to grow. He apparently did not enjoy situations where he could not have complete control over everything that happened in his company. Delegation had also begun to be necessary.

One of his explanations for the problem was that it is difficult to recruit a good manager and even harder to train one, to ensure that everything works. That is probably true, but it was also clear that he personally had problems with letting go. It was obviously not easy to let someone else take control of what happened in the production hall.

From his own statements one could also imagine that he still was happier producing in the workshop dressed in work clothes, than in the CEO's office dressed in a suit. Upward class mobility is often a long and painful journey for the owner of a small company that is becoming the medium or large one.

And not only that. For Orhan, it was not just about his identity crisis as worker, but also about the crisis for his work ethic as a craftsman. Leaving the production hall, he loses touch with his own original work and its visible and tangible results. All this work will suddenly become simply a means that will lead to profits. The purpose of the work, and even the meaning of life, can sometimes feel as if it has been lost. For Orhan, this was a new situation that he had to adjust to.

\subsection{Barriers against effort}

Let us now focus on Orhan's so-called break-out strategies, in connection with the development of the company's organization.

Orhan's permanent quest was to obtain a strong and capable leadership team. Before the crisis, he had four employees in management, including five in the period when the business was at its best. Now there were just two of the management team, including Orhan himself. His daughter worked previously on the accounting and billing. She was currently on maternity leave, but still did some of this paperwork at home.

The biggest problem was finding the right development manager. So far he had tried several people but had not been really happy with any of them. He claimed that they lacked the required capacity, as well as the contacts necessary for enterprise development. Right now, he had hired a man in this post, and he was expecting that things would be fine with him.

He held several management positions in Tetrapak ... and I wanted to test him. With his experience and contacts, I think it may go well for us. He'll open the door for us to some companies to which we previously had no access. Anyone who wants to grow must have more contacts and more new business contracts. It does not happen overnight, it is impossible! We have already been in existence for ten years and already have a name, at least locally, but now you have to go a little further. 
One way to go a little further was to try to buy an existing business. It was about a year before the crisis, and Orhan focused on a robust 80 -year-old family business with 13 or 14 employees and annual sales of 16 million-17 million kronor. The company was in a small town north of Malmö.

Two brothers were the owners and it was their father who started the company. They do not even have a website, but were still getting the orders from all over Sweden... And I went there, checked everything, and everything was in order. The owners wanted to retire and therefore they wanted to sell the company. My idea was that through the purchase of the company I could lift my business to a higher level ...

However, an obstacle turned up on the road. It had put there by the bank, the one that Orhan worked with for over ten years.

\subsection{Professionalism versus ethnicity}

In the bank's local office, Orhan was, or expected to be, according to his own estimation, one of the most important clients, given that his annual turnover in recent years was more than 30 million kronor. The proposed price for the company he wanted to buy was six million kronor. Before he left to visit the company, he called his contact person at the bank and asked if the bank would be willing to support him if he decided to buy. The response was positive. After he visited the company and decided to go ahead with the deal, he contacted the bank again.

And now I called my bank again and asked what I could expect. 50:50, they said. I had the money and can afford 50 per cent of the payment. But I know that in these situations the bank used to take on 80 per cent and the customer only 20 per cent of the investment. Besides, in my case everything was so serious, even the broker who sold the company was from the same bank. Yet my bank contact had no confidence in me and he offered me only 50:50. I did not make any comment at all. After five or six days, after pulling myself together, I called the broker and said that I would refrain from buying. Even then, I wanted to leave the bank but it was vacation time and later I calmed down and stayed with it. But the bitterness remained...

Having come so far in the story of Orhan, we should pay attention to the one of the basic problems in this context: banks' attitudes towards small entrepreneurs in general, and immigrant small entrepreneurs in particular.

The Swedish money market is still dominated by a small number of large players. The big banks also have a rigid attitude towards small business customers, especially migrant small businesses, jeopardizing the economic climate for small business (Slavnic, 2007).

Research results from other European countries show that banks tend to discriminate against growing small businesses owned by immigrants (Rath and Swagerman, 2011), even in cases where their former business performance has been extraordinarily good (Ram et al., 2003). Banks tend instead to lend money only to those companies that are comparable to a so-called standard entrepreneur (Apitzsch, 2003).

A 'standard entrepreneur' is usually a young or a middle-aged man from the native population, who starts his business with already secured finance and relatively favourable social and political circumstances. The policies of most banks and other financial institutions are based on this standard entrepreneur when assessing their clients' loan applications. Any applicant who deviates from the norm is unlikely to have a loan application approved. Orhan's experience suggests that this also applies in Sweden.

Later in our conversation Orhan told me that he finally broke with the bank. It happened shortly after the failed investment experiment. At that time Orhan decided to separate his production business from activities involved in supplying labour, and placed them in two different companies. He wanted to demonstrate his determination to treat his temporary employment business as a temporary phenomenon by formally separating the two activities.

His new agency had contracted several companies and held payment for 40 days' work. To be able to pay wages to his employees from the first month, he turned again to his bank and applied for an overdraft facility of 400000 crowns.

And so I went first to the bank, got the documents, asked if I could get the loan. They said 'there is no problem here, it should be fine'. And so I went on vacation. When I came back, I called again to check the situation and the bank said 'It's OK, you can get the overdraft facility, but on condition that you personally provide a guarantee for this loan'. It was not really a problem for me, I had done it all on my own, but now I saw that they had no confidence in me. They stopped people on the streets in Latvia to persuade them to take a loan, without bail or anything ... But back home in 
Sweden I could not get even overdraft facility - this was not a loan but only an overdraft facility even if I had a company with annual sales of 30 million kronor. It meant that they did not trust me. And I left the bank instantly. Afterwards the bank called me ten times, and said 'come back, you can get good conditions, and so on', and asked 'what did you get from your new bank?'. Nothing, I said, I was not looking for anything either, I just went over to the other bank.

Monder Ram et al. (2003) believe that at least three steps can be taken to stop banks' obviously discriminatory behaviour. First, banks should work on clearer criteria and provide greater transparency in assessing loan applications. Second, officials in consulting and banking services in general should develop a more proactive approach towards their small business customers with an immigrant background. Finally, banks should adhere more consistently to principles of equal opportunity, with special attention to the recruitment of officials at all levels. Officials should better match the current ethnic structure of their customers and the general population (Ram et al. 2003: 679).

These measures were designed for British conditions, but they would certainly help Swedish banks, too, to improve their business practices. At least, their small business customers with foreign backgrounds would have better financial support for their activities. As things stand today, Orhan is still not able to expect the positive effects of these possible measures.

Our conversation gradually got closer to the specific problems that he, as an immigrant, had to contend with in everyday life. Could his personal qualities and his social network, which had so effectively helped him to make the break-in, help him equally effectively to develop his business further?

It is not easy with that sort of prejudice. You know how it is. I do not perceive myself as an immigrant, although I am one of them. I want to be perceived as equal to others, especially when I do business. But it is not quite so even though I want it to be so. I repress it in me, working, trying to be accurate in the business, having quality. And thus we have customers who have tried us, they will stay with us. But it is difficult to enter other markets and show what you can do. For as soon as they hear my name ... Orhan, you know, this still occurs frequently.

One problem with trust in this context is that it has an emotional component, which makes it non-transferable (Barbalet, 2009). Thus, there is no guarantee that the trust gained in one's relationship with a certain person can be transferred to one's relationships with other people.

In Orhan's case, as we could see, there were no problems during the break-in phase. But in the new (breaking-out) situation, when the number of players he came into contact with was much higher, his 'social capital' was no longer convertible. It was created in and related to the local market, a small number of partners and a small customer base. This means that, in principle, with each new business contact Orhan must build his trust relationships from scratch, which of course increases his so-called transaction costs. Yet he has no guarantee that these costs would be reduced in the next business contact.

The following passage exemplifies Orhan's never-ending struggle for trust. This involves cooperation with a municipal enterprise, which he had developed over many years and where the staff also were very pleased. At some point in time a official appeared in the enterprise's management who started to display an openly hostile attitude towards Orhan's company. She obviously wanted to suspend cooperation between two companies.

Two years already, she has not done anything but tried to throw us out. But because of the other people in this company, who know us well and who trust us, she has not managed to push us out. But she seems to be such a person that her colleagues also have problems with her. And therefore I do not understand her behaviour towards me as anti-immigrant. But this also occurs.

Orhan himself does not want to see his ethnicity as the main feature of his personality. Even less does he want to see it as the most important feature of his business activities. He wants to see himself as equal to others, even in situations that objectively are directly discriminatory. He tries to continue with business as usual, to be accurate in the business, to have quality and not to worry about conflicts with seemingly ethnic overtones. Despite this, the ethnic aspects are imposed upon him and his activities by the social structure that surrounds him.

In fact, discrimination (Note 4) affects his business in two ways. In the first place, it imposes extra costs upon his business activities. An example is his bank offering him systematically less favourable loan terms: it is quite obvious that his ethnicity is perceived as a decisive risk factor that may legitimize such behaviour. 
The second problem is that such treatment has forced him to make a number of problematic business decisions. In my opinion, both his decision not to proceed with the acquisition and his decision to change bank are emotional reactions to unfairness rather than the result of rational economic calculation.

\subsection{Breaking out}

In the paper's first section, with the help of the methodological concept of 'mixed embeddeness' I attempted to describe and explain how Orhan started and established his business. Here, using the same method, I will try to summarize the current state and prospects of Orhan's company. First, it is clear that Orhan wants his company to grow. Second, his clearly stated ambition is to develop a business for his own products. Third, labour hire, which he perceives as a temporary business that is less important for his future, continues to be more lucrative than the production of commodities and services. Why is this so? To find answers, let us first consider Orhan's strategy, and then the obstacles in the path to his planned development.

The basic elements of his current strategy are still his positive, progressive and quality-oriented work ethic, and his trusting, loyal and generally correct approach to his partners, customers and employees. With these characteristics as the foundation, he has adopted a further set of measures designed to get him into markets with higher thresholds, such as applying for ISO certificates, recruiting or educating a qualified workforce, investing in new machinery, improving production organization and investing in new management with the right skills and the right contacts.

The attempt to buy a company with similar activities, but located elsewhere and serving other customers, testifies that Orhan also wants to expand his activities beyond the local market.

This is what Orhan does, what he would like to do and what he hopes to do in the future. But it is still impossible to state whether his company really will achieve the desired development. What are the obstacles that stand in the way of the planned development of Orhan's company?

First, the structure of the market that Orhan wishes to enter is completely different from that of the local market where he started his business. The new market is often more institutionalized and has higher entry requirements. A higher degree of institutionalization does not mean more or stricter regulation, but rather more standardized business relationships between market participants. This implies generally long-term business contacts that are based on strong mutual loyalty and often informal relationships (Engelen, 2001). These networks of business cooperation and competition are usually more closed and less accessible to newcomers. In that sense, Orhan's ISO certification, dedication to quality in production, and reliability in his business relations are certainly necessary, but unfortunately might be inadequate conditions for the break-out. Leadership with the right contacts can be helpful in these efforts, but, as we have seen, Orhan has not yet managed to recruit such management personnel.

The second obstacle is that entry to these new markets requires access to capital. Orhan's experience with his bank confirms previous research showing that in his situation it is not at all easy to obtain support from banks.

The third structural barrier is reflected in political rhetoric in Sweden, which since 1990 has continuously proclaimed a radical U-turn in the creation of better conditions for SMEs. However, in reality economic policy has never stopped focusing on the majors, while SMEs have been systematically neglected. This discrepancy between political rhetoric and political practice has been even clearer in relation to small businesses owned by immigrants (Slavnic, 2007).

The fourth obstacle has to do with Orhan's ethnicity. Although he wants to confine his ethnicity to the private sphere and not to mix it with the business, his history shows how ethnicity has been ascribed to his business, how it could negatively affect his business, and how hard it is to resist this.

The fifth obstacle is related to the fact that the trust obtained in previous social interactions, because of its emotional component, cannot be reused as a kind of social capital with a universal value in new social interactions. This means that Orhan's accumulated trust from his break-in phase does not necessarily help him much during the break-out phase.

Finally, as an entrepreneur Orhan must be able to adjust personally to the change his growing business is going through. We saw earlier in this chapter that his work ethic in some way is comparable to that of the traditional craftsman. But his class identity is, as we have seen, is still a working class one. Dealing with his own upward class mobility, learning to delegate tasks formerly done by himself, can sometimes be really difficult for the business owner trying to break out. Values or personal characteristics, which in themselves are quite unproblematic, can suddenly become a problem even for the company's development. In Orhan's case, for instance, his attitude to work - with the motto 'better slowly with good quality, than quickly with a lack of quality' - in tougher (break-out) conditions may serve more as an obstacle to development than as force driving it. 


\subsection{Orhan's destiny: to dampen class conflicts for free?}

I have briefly summarized the obstacles that have so far prevented the production part of Orhan's business from developing. The labour hire part, as we already know, had done much better. One possible explanation for this may be a general trend towards economic flexibilization.

The big companies that are Orhan's customers 'earn' flexibility by being able to use only as many workers as they need in the short term. This kind of flexibility has the result, however, that more and more people increasingly go back and forth between an active and a reserve labour army. For these people it would mean not only increased employment insecurity but also all kinds of social, psychological and health strains. Earlier, during the so-called golden age of the welfare state, such anomalies could be avoided because the state used to compensate for market failures. Nowadays, parallel with the growth of the neoliberal economy, this kind of compensation is generally weakening (Jessop, 2002; Slavnic, 2010), which increases the risk of conflicts between workers and their employers.

Orhan's good relationship with his employees - obviously coloured by the feeling that they in fact belong to the same (working) class - creates a mutual loyalty that reduces the risk of conflict, even in situations in which Orhan had to dismiss a large proportion of his employees.

But in my view it is not he who earns most from this, but his client companies, who themselves certainly cannot expect the same tolerance level in their relationships with employees. Orhan not only organizes workers for them, when they need them and for the desired time period; he also dampens the class conflicts that may arise in the neoliberal work environment.

Viewed in this way, Orhan's class identity can be perceived as a kind of symbolic capital, which makes it possible for him to get any contracts at all with the majors. However, he will never benefit from the extra profits - generated with the help of his symbolic capital - that the big businesses make.

Orhan faces yet another dilemma. In order to make a break-out for his production operations, he must get rid of his working-class identity; but at the same time, by doing this he becomes less attractive to customers of his staffing service. Hereby it becomes clear that the staffing part of his business is actually an obstacle to the development of the productive part of his business.

However, if he gives up his ambition to develop his own production and products, he still can safely remain in the staffing market. But his fate will then probably be to continue to be responsible for the function of dampening of class conflict between capital and labour, without being paid for it.

\section{Concluding remarks}

The story I have just told is about a small business owner with an immigrant background who wants his company to grow. His business strategies have been analyzed both as a part of his own biographical work, and as they were influenced and framed by broader political, economic and social processes. It has been shown how his own personal qualities in combination with opportunity structures in the local market provided favourable conditions for his break-in. Breaking out, however, seems to be presented with different types of barriers, such as lack of access to capital, discrimination, and the fact that new markets may consist of different sorts of network that are in its turn more difficult for new actors to enter. Most of the issues raised in this paper have already been addressed by growing literature in the field. The added value of this paper is however the systematic and detailed way in which these issues, with the help of biographical method, have been analyzed and discussed. Conclusions, regarding Orhan's real chances to make a break-out were, as we could see, not especially optimistic.

Yet I do not want to close this article on such a pessimistic note. To be sure, the social structure is often rigid and provides individuals with little space to achieve their life plans. However, individuals in their biographical work are, as Prue Chamberlayne (2004) reminds us, not only passive objects. In their quest to live according to their own life plans, they often find new and unexpected potential in themselves, allowing them to achieve goals that neither they themselves nor society at large originally thought possible.

I really hope that Orhan succeeds in his effort to realize his most important business and private life plans.

\section{References}

Alheit, Peter. (1994). 'The "Biographical Question" as a Challenge to Adult Education', International Review of Education 40 (3/5): 283-98. http://dx.doi.org/10.1007/BF01257782

Andersson, Pernilla and Eskil Wadensjö. (2004a). Temporary Employment Agencies: A Route for Immigrants to Enter the Labour Market? Discussion Papers Series IZA DP No. 1090. Bonn: Institute for the Study of Labor. 
Andersson, Pernilla and Eskil Wadensjö. (2004b). Self-Employed Immigrants in Denmark and Sweden: A Way to Economic Self-Reliance? Discussion Papers Series IZA DP N0. 1280. Bonn: Institute for the Study of Labor.

Apitzsch, Ursula. (2003). 'Gaining Autonomy in Self-employment Processes: The Biographical Embeddedness of Women's and Migrants' Business', International Review of Sociology: Revue Internationale de Sociologie 13(1): 163-82. http://dx.doi.org/10.1080/0390670032000087041

Apitzsch, Ursula and Irini Siouti. (2007). 'Biographical Analysis as an Interdisciplinary Research Perspective in the Field of Migration Studies', Research Integration, Heslington: University of York.

Barbalet, Jack. (2009). 'A Characterization of Trust, and its Consequences', Theory and Society 38: 367-82. http://dx.doi.org/10.1007/s11186-009-9087-3

Barrett, Giles, Trevor Jones and David McEnvoy. (1996). 'Ethnic Minority Business: Theoretical Discourse in Britain and North America', Urban Studies 33: 783-809. http://dx.doi.org/10.1080/00420989650011825

Barrett, Giles, Trevor Jones and David McEnvoy. (2003). 'United Kingdom: Severely Constrained Entrepreneurialism', in Robert Kloosterman and Jan Rath (eds), Immigrant Entrepreneurs: Venturing Abroad in the Age of Globalization. Oxford and New York: Berg.

Bauder, Harald. (2005). 'Habitus, Rules of the Labour Market and Employment Strategies of Immigrants in Vancouver, Canada', Social \& Cultural Geography 6(1): 81-97 http://dx.doi.org/10.1080/1464936052000335982

Bonacich, Edna. (1973). 'A Theory of Middleman Minorities', American Sociological Review 38: 583-94.

Bonacich, Edna and John Modell. (1980). The Economic Basis of Ethnic Solidarity. Berkeley and Los Angeles: University of California Press.

Chamberlayne, Prue. (2004). 'Biographical Methods and Social Policy in European Perspective', in Prue Chamberlayne, Joanna Bornat and Ursula Apitzsch (eds), Biographical Methods and Professional Practice. An international perspective. Bristol: Policy Press.

Engelen, Ewald. (2001). "'Breaking In" and "Breaking Out": A Weberian Approach to Entrepreneurial Opportunities', Journal of Ethnic and Migration Studies 27(2): 203-23. http://dx.doi.org/10.1080/13691830020041570

Giddens, Anthony. (1984). The Constitution of Society. Outline of the Theory of Structuration, Cambridge: Polity Press.

Giddens, Anthony. (1990). The Consequences of Modernity. Cambridge: Polity Press.

Jessop, Bob. (2002). The Future of the Capitalistic State. Cambridge: Polity Press.

Jones, Trevor. (1981). 'Small Business Development and the Asian Community in Britain', New Community 9: 467-77. http://dx.doi.org/10.1080/1369183X.1981.9975722

Jones, Trevor, Giles Barrett and David McEvoy. (2000). 'Market Potential as a Decisive Influence on the Performance of Ethnic Minority Business', in Jan Rath (ed.), Immigrant Businesses - The Economic, Political and Social Environment. Houndmills, Basingstoke and London: Macmillan Press.

Kloosterman, R. C. (2010). "Matching opportunities with resources: A framework for analysing (migrant) entrepreneurship from a mixed embeddedness perspective." Entrepreneurship \& Regional Development 22(1): 25-45. http://dx.doi.org/10.1080/08985620903220488

Kloosterman, Robert, Jouanne van der Leun and Jan Rath. (1999). 'Mixed Embeddedness: (In)formal Economic Activities and Immigrant Business in the Netherlands.' International journal of urban and regional research 23: 252-266. http://dx.doi.org/10.1111/1468-2427.00194

Kloosterman, Robert and Jan Rath. (2001). 'Immigrant Entrepreneurs in Advanced Economies: Mixed Embeddedness Further Explored', Journal of Ethnic and Migration Studies 27: 189-202. http://dx.doi.org/10.1080/13691830020041561

Kloosterman, Robert and Jan Rath. (2003). 'Introduction', in Robert Kloosterman and Jan Rath (eds), Immigrant Entrepreneurs: Venturing Abroad in the Age of Globalization. Oxford and New York: Berg.

Levent, Tüzin Baycan, Enno Masurel and Peter Nijkamp. (2006). 'Break-Out Strategies of Ethnic Entrepreneurs', in Teresa de Noronha Vaz, Eleanor J. Morgan and Peter Nijkamp (eds), The New European Reality: Strategies for Small Firms. Aldershot: Ashgate. 
Lundin, Johan, A. (2007). Malmö Industristaden: Addo, Cementa, Ljungmans, Kockums, Malmö museers e-skrifter nr-5.

Mason, Suzanne and Aleksandra Ålund. (2001). Perceptions of Self-employment Policies and Practices. Final and Scientific Report for the TSER-projekt 'Self-employment Activities Concerning Women and Minorities - Their Success or Failure in Relation to Social Citizenship Policies'. EU project No. PL97 3211. University am Main, Germany. Umeå: Umeå University.

McEvoy, David and Trevor Jones. (1993). 'Relative Economic Welcomes: South Asian Retailing in Britain and Canada', In H. Rudolph and Mirjana Morokvasic (eds), Bridging States and Markets. Berlin: Edition Sigma.

Misztal, Barbara. (1996). Trust in Modern Societies: The Search for the Basis of Social Order: Cambridge: Polity Press.

Olofsdotter, Gunilla. (2004). 'Bemanningsföretag - en möjlighet för vem?', in Lars-Erik Wolvén and Eskil Ekstedt (eds), Företagande och gemenskap - små företags kultur, samverkan och konkurrens. Stockholm: Arbetsliv i omvandling, 2004:7. Arbetslivsinstitutet, Institutet för tillväxtpolitiska studier och Mitthögskolan.

Olofsdotter, Gunilla. (2006). 'I skärningspunkten mellan motstridiga krav och intressen - om ledarskap i bemanningsföretag', in Arbetsliv i omvandling, 2006:9, Arbetslivsinstitutet.

Olofsdotter, Gunilla. (2009). 'Personalinhyrning - från tillfällig bemanningslösning till permanent samarbetspartner', in Arbetet i Människors liv, Göteborgs Universitet, 13-14 maj 2009.

Povrzanovic-Frykman, Maja. (2009). "Views from Within - Bosnian Refugees' Experience Related to their Employment in Sweden", in Pieter Bevelander, Mirjam Högström och Sofia Rönqvist (eds.), Resettled and Included? The Employment Integration of Resettled Refugees in Sweden. Malmö: Malmö University

Purcell, Kate Purcell John. (1998). 'In-sourcing, Outsourcing, and the Growth of Contingent Labour as Evidence of Flexible Employment Strategies', European Journal of Work and Organizational Psychology 7: 39-59. http://dx.doi.org/10.1080/135943298398952

Ram, Monder and Guy Hillin. (1994). 'Achieving “Break-out”: Developing Mainstream Ethnic Minority Business', Small Business Enterprise and Development 1(1): 15-21. http://dx.doi.org/10.1108/eb020936

Ram, Monder, David Smallbone, David Deakins and Trevor Jones. (2003). 'Banking on "Break-out': Finance and the Development of Ethnic Minority Business', Journal of Ethnic and Migration Studies 29(4): 663-81. http://dx.doi.org/10.1080/1369183032000123440

Ram, M. and T. Jones. (2008). "Ethnic-minority businesses in the UK: a review of research and policy developments." Environment and Planning C: Government and Policy 26: 352-374. http://dx.doi.org/10.1068/c0722

Rath, Jan. (2001). 'Research on immigrant ethnic minorities in the Netherlands', in P. Ratckligge (ed.), The Politics of Social Science Research. 'Race', Ethnicity and Social Change. Houndmills and Basingstoke: Palgrave.

Rath, Jan. (2002). 'Needle Games: Mixed Embeddedness of Immigrant Entrepreneurs', in Jan Rath (ed.), Unravelling the Rag Trade: Immigrant Entrepreneurship in Seven World Cities. Oxford: Berg Publishers.

Rath, J., and Swagerman, A. (2011). Promoting ethnic entrepreneurship in European Cities. Luxemburg: CLIP Network: Cities for Local Integration Policy.

Rosenthal, Gabriele. (1993). 'Reconstruction of Life Stories. Principles of Selection in Generating Stories for Narrative Biographical Interviews', The Narrative Study of Lives 1 (1): 59-91.

Sennett, Richard. (1998). The Corrosion of Character: The Personal Consequences of Work in the New Capitalism. New York and London: W.W. Norton.

Sennett, Richard. (2003). Respect: The Formation of Character in a World of Inequality. London: Allen Lane.

Simmel, Georg. (1990). The Philosophy of Money, London, Routledge

Slavnic, Zoran. (2007). Forskning och politik relaterat till småföretagande bland invandrare i Sverige. Rapportnr. 2007:21, Linköping, Länsstyrelsen Östergötland.

Slavnic, Zoran. (2008). Integration into Vertical Mosaic: Reflections on the History of Integration Policy, IMER Research and Journalism in Sweden since 1960s. Migracijske i etnicke teme, 24(4), 371-388.

Slavnic, Zoran. (2010). 'Political Economy of Informalisation', European Societies 12(1): 3-24. http://dx.doi.org/10.1080/14616690903042724 
Sztompka, Piotr. (1999). Trust - A Sociological Theory. Cambridge: Cambridge University Press.

Wright Mills, C. (1951/2002). White Collars: The American Middle Class. Oxford and New York: Oxford University Press.

\section{Notes}

Note 1. See, for example, Jones (1981); McEvoy and Jones (1993); Barrett, Jones and McEvoy (1996); Jones, Barrett and McEvoy (2000); Barrett, Jones and McEvoy (2003); Ram and Jones (2008).

Note 2. Kloosterman, van der Leun and Rath (1999); Kloosterman and Rath (2001; 2003); Rath (2001; 2002); Kloosterman, (2010).

Note 3. Adult vocational training, an employment policy programme.

Note 4. For discussion about the discrimination as a general catalyst for recommodification see Slavnic (2008). 